\title{
SISTEM PENGETAHUAN NELAYAN TERHADAP KESEHATAN IBU DAN ANAK DI NAGARI PASAR LAMA MUARA AIR HAJI, KECAMATAN LINGGO SARI BAGANTI, KABUPATEN PESISIR SELATAN
}

\author{
Yunarti ${ }^{1}$, Hendrawati ${ }^{2}$, Sri Meiyenti ${ }^{3}$
}

\begin{abstract}
A high level of knowledge in society will increase the level of participation, especially the participation of health. This impact on cultural behavior of public health, especially maternal and child health issues have started well. Most of the mothers in the Pasar Lama Muara Air Haji village already have a system of knowledge that is high enough on the problem of health care of pregnant women and their children. This is also supported by the role of midwives and health volunteers help disseminate health through education programs and integrated health services
\end{abstract}

Keywords: Knowledge, Pregnant Mother, Child Care, Village

\section{PENDAHULUAN \\ 1. Latar Belakang Masalah}

$\mathrm{S}$ emakin disadari bahwa budaya tidak bisa diabaikan dalam mempengaruhi status kesehatan masyarakat nelayan. Karena itu riset tentang budaya kesehatan masyarakat nelayan dalam upaya peningkatan status kesehatan sangatlah penting untuk dilakukan. Konsekuensi logis harus disadari bahwa beranekaragamnya budaya yang ada di wilayah Indonesia terutama di daerah pesisir pantai memerlukan pemahaman yang cermat untuk setiap daerah dengan etnis yang ada di wilayah tersebut. Pemahaman budaya secara spesifik, dengan menggali kearifan lokal akan dapat digunakan sebagai strategi upaya kesehatan dengan tepat secara lokal spesifik.

Secara obyektif setiap kelompok masyarakat tertentu terutama pada masyarakat nelayan mempunyai persepsi kesehatan (konsep sehat sakit) yang berbeda. Hal ini sangat ditentukan oleh kebudayaan masyarakat yang bersangkutan. Setiap orang yang terganggu kesehatannya akan mencari jalan untuk menyembuhkan diri dari gangguan kesehatan atau penyakit yang dideritanya. Pencarian pengobatan dengan self treatment maupun upaya mencari tenaga kesehatan merupakan upaya manusia mengatasi permasalahannya. Budaya masyarakat nelayan yang menjadi ciri khas pola kehidupan, dan yang telah menjadi tradisi turun temurun, memiliki potensi yang besar untuk mempengaruhi kesehatan baik dari sisi negatif maupun positif. Memahami status kesehatan masyarakat berdasarkan budaya merupakan upaya salah satu upaya meningkatkan status kesehatan itu sendiri, terutama status kesehatan ibu dan anak.

Masalah kesehatan ibu dan anak tidak terlepas dari faktor-faktor sosial budaya dan lingkungan di dalam masyarakat nelayan dimana mereka berada. Faktor-faktor kepercayaan dan pengetahuan budaya seperti konsepsi-konsepsi mengenai berbagai pantangan, hubungan sebabakibat antara makanan dan kondisi sehatsakit, kebiasaan, dan pengetahuan tentang kesehatan, dapat membawa dampak positif maupun negatif terhadap kesehatan. Hal tersebut merupakan potensi dan kendala yang perlu digali.

Namun demikian, Angka Kematian Ibu (AKI) dan Angka Kematian Bayi (AKB)

\footnotetext{
${ }^{1}$ Penulis adalah Dosen tetap Jurusan Antropologi FISIP Universitas Andalas

2 Penulis adalah Dosen tetap Jurusan Antropologi FISIP Universitas Andalas

${ }^{3}$ Penulis adalah Dosen tetap Jurusan Antropologi FISIP Universitas Andalas
} 
di Indonesia masih cukup tinggi dibandingkan Negara ASEAN lainnya. Survei Demografi Indonesia (SDKI) 2012 memberikan data bahwa AKI 359 per 100.000 kelahiran hidup dan AKB 32 per 1000 kelahiran hidup. Berdasar kesepakatan global MDGs (Millenium Development Goal) tahun 2000 diharapkan tahun 2015 terjadi penurunan AKI menjadi 102 per 100.000 kelahiran hidup dan AKB menjadi 23 per 1000 kelahiran hidup. Berbagai upaya Kesehatan lbu dan Anak (KIA) dilakukan untuk mengatasi perbedaan yang sangat besar antara AKI dan AKB di Negara maju dan di Negara berkembang seperti Indonesia. Data Riskesdas 2007 menunjukkan prevalensi HT sebesar $31,7 \%$, Balita stunting $36,8 \%$ dan akses sanitasi $43 \%$, hal ini menunjukkan bahwa masalah kesehatan tidak hanya pada status kesehatan ibu dan anak saja, namun termasuk masalah penyakit tidak menular, gizi dan PHBS.

Data Susenas 2007 menunjukkan bahwa hanya sekitar 35\% penduduk sakit yang mencari pertolongan ke fasilitas pelayanan kesehatan. Tampaknya penduduk cukup banyak yang tidak memanfaatkan fasilitas kesehatan terbukti $55,4 \%$ persalinan terjadi di fasilitas kesehatan dan masih banyak yaitu 43,2 persen melahirkan di rumah. Dari jumlah ibu yang melahirkan di rumah 51,9 persen ditolong bidan dan masih ada 40,2 persen yang ditolong dukun bersalin (Riskesdas 2010). Data Riskesdas 2010 menunjukkan bahwa setahun sebelum survei, $82,2 \%$ persalinan ditolong oleh tenaga kesehatan namun masih ada kesenjangan antara pedesaan $(72,5 \%)$ dan perkotaan $(91,4 \%)$. Masih tingginya pemanfaatan dukun bersalin serta keinginan masyarakat untuk melahirkan di rumah, terkait dengan faktorfaktor sosial budaya.

Berdasarkan data statistik dari Dinas Kesehatan Kabupaten Pesisir Selatan tahun 2013 bahwa jumlah kematian ibu di Kab. Pesisir Selatan dari tahun $2000 \mathrm{~s} / \mathrm{d}$ 2010 cenderung naik turun setiap tahunnya. Tahun 2000 jumlah kematian ibu sebanyak 6 jiwa $(\mathrm{AKI}=88$ per 100.000 kelahiran hidup), tahun 2001 meningkat menjadi 13 jiwa dan tahun 2002 meningkat mencapai 19 jiwa, namun pada tahun 2003 turun menjadi 16 jiwa serta tahun 2004 turun lagi menjadi 10 jiwa, tahun 2005 sebanyak 15 jiwa dan 2006 turun menjadi 6 jiwa. Kemudian tahun 2007 kembali meningkat menjadi 15 jiwa dari 6439 kelahiran hidup ( AKI $=233$ per 100.000 kelahiran hidup) . Tahun 2008 meningkat menjadi 17 jiwa dari 7510 kelahiran hidup ( $\mathrm{AKI}=226$ per 100.000 kelahiran hidup). Tahun 2009 jumlah kematian ibu sebanyak 12 jiwa sedangkan tahun 2010 mengalami penurunan lagi dengan jumlah kematian ibu 9 jiwa Berikut jumlah kematian ibu tahun 2006 sampai dengan tahun 2010. Hal ini juga diikuti oleh jumlah Kematian Bayi di Kab. Pesisir Selatan pada tahun 2002 tercatat 76 jiwa dari 7771 kelahiran hidup (AKB $=10$ per 1000 kelahiran hidup), tahun 2003 tercatat mencapai 101 jiwa dari 7771 kelahiran hidup (AKB $=13$ per 1000 kelahiran hidup), sedangkan pada tahun 2004 memperlihatkan keberhasilan yang signifikan yaitu jumlah kematian bayi turun menjadi 81 jiwa dari 8538 kelahiran hidup (AKB $=9$ per seribu kelahiran hidup), Tahun 2005 jumlah kematian bayi kembali turun menjadi 74 jiwa dari 7872 kelahiran hidup (9 per 1000 kelahiran hidup). Namun pada tahun 2006 dan 2007 terjadi peningkatan yang sangat signifikan jumlah kematian bayi setelah dilakukan perbaikan sistem pelaporan dan survey kematian bayi yaitu 107 jiwa tahun 2006 (AKB = 13 per 1000 kelahiran hidup) dan 203 jiwa tahun 2007 ( $\mathrm{AKB}=26$ per 1000 kelahiran hidup). Tahun 2008 turun lagi menjadi 101 jiwa $(A K B=13$ per 1000 kelahiran hidup). Hal tersebut memperlihatkan kondisi kesehatan ibu dan anak dianggap cukup mengkhawatirkan apabila dilihat dari sudut kematian ibu dan anak.

Hasil penelitian riset etnografi kesehatan tahun 2012 yang dilakukan Kementerian Kesehatan RI di 12 etnis di Indonesia menunjukkan masalah kesehatan ibu dan anak terkait budaya kesehatan sangat memprihatinkan. Kepercayaan tentang hal-hal mistis masih melekat kuat pada budaya mereka, antara lain mitos bahwa ibu hamil rentan untuk diganggu oleh roh jahat sehingga ibu hamil harus menjalani ritual dan memakai jimat serta mematuhi pantangan dan larangan agar terhindar dari gangguan roh jahat. Pantangan mengkonsumsi makanan yang justru mengurangi asupan pemenuhan gizi ibu hamil sangat mempengaruhi status gizi ibu hami. 
Keharusan untuk tetap bekerja keras sampai mendekati persalinan bagi ibu hamil juga sangat membahayakan baik bagi ibu maupun janinnya. Mereka beranggapan bahwa ibu yang bekerja keras saat hamil akan memudahkan dan melancarkan persalinannya. Pilihan utama untuk persalinan dilakukan dirumah dan dibantu oleh dukun karena ibu merasa aman dari gangguan roh jahat serta nyaman karena ditunggui oleh keluarga. Pemotongan tali pusat dengan sembilu (bambu yang ditipiskan dan berfungsi seperti pisau) masih banyak digunakan untuk memotong tali pusat bayi yang baru dilahirkan.

Ramuan yang berasal dari berbagai tumbuhan, baik yang diminum maupun yang dimasukkan dalam liang vagina, juga dipercaya dapat mempercepat kesembuhan dan mengeringkan vagina ibu yang habis bersalin. Selain itu kebiasaan pijat baik pada ibu paska melahirkan mupun pada bayi baru lahir juga masih dilaksanakan pada etnis tertentu. Kepercayaan memandikan bayi yang baru lahir dengan air dingin, di sungai, danau atau sumber air lain, akan menjadikan bayi lebih kuat baik fisik maupun mentalnya.

Pola dasar kesehatan masyarakat tidak terlepas dari masalah sosial budaya. Rencana strategi Kementerian Kesehatan tahun 2010-2014 tentang program Gizi dan KIA menyebutkan indikator tercapainya sasaran hasil tahun 2014 yaitu persentase pertolongan persalinan oleh tenaga kesehatan terlatih sebesar 90\% dan kunjungan neonatal pertama (KN1) sebesar $90 \%$ serta persentase balita yang ditimbang berat badannya (jumlah balita ditimbang/balita seluruhnya atau D/S) sebesar 85\% (Kemenkes, 2010).

Luaran yang diharapkan adalah meningkatnya kualitas pelayanan ibu dan anak serta pelayanan reproduksi. Untuk mencapai hal tersebut bukanlah hal mudah. Strategi pembangunan kesehatan seperti yang tertuang dalam Rencana Pengembangan Jangka Panjang Bidang Kesehatan tahun 2005 - 2025 antara lain menyebutkan tentang pemberdayaan masyarakat. Peran masyarakat dalam pembangunan kesehatan semakin penting. Masalah kesehatan perlu diatasi oleh masyarakat sendiri dan pemerintah. Keberhasilan pembangunan kesehatan, penyelenggaraan berbagai upaya kesehatan harus berangkat dari masalah dan potensi spesifik daerah termasuk di dalamnya sosial dan budaya setempat. Pemberdayaan masyarakat berbasis pada masyarakat artinya pembangunan kesehatan berbasis pada tata nilai perorangan, keluarga dan masyarakat sesuai dengan keragaman sosial budaya, kebutuhan permasalahan serta potensi masyarakat (modal sosial) (Kemenkes RI, 2012).

Indonesia yang terdiri dari ribuan pulau besar dan kecil yang dihuni ratusan suku bangsa dengan berbagai ragam budaya telah memberikan suatu kekhasan tersendiri. Perilaku masyarakat khususnya masyarakat tradisional tercermin dari perilaku mereka memanfaatkan kekayaan intelektual masyarakat lokal berupa pengetahuan tradisional mereka dan keanekaragaman hayati di lingkungannya. Praktek budaya terkait kesehatan tersebut sebagian diklaim oleh orang-orang dengan pengetahuan "modern" sebagai salah satu penyebab buruknya status kesehatan masyarakat setempat. Sebagai contoh, dalam budaya "Sei" dimana bayi yang baru lahir ditempatkan dalam rumah yang dibawahnya diberi pengasapan telah menyebabkan tingginya angka kesakitan gangguan pernapasan pada bayi baru lahir. Beberapa kelompok masyarakat di Jawa masih mempunyai kebiasaan memberikan makanan pisang dilumat dengan nasi untuk diberikan kepada bayi usia dini (kurang 4 bulan) sehingga bayi mempunyai risiko terganggu saluran pencernaannya.

Kekayaan budaya Indonesia dari berbagai suku bangsa yang tersebar di seluruh Indonesia telah mewarnai upaya kesehatan. Upaya kesehatan bisa berupa pelayanan konvensional maupun tradisional dan komplementer berupa kegiatan preventif, promotif, kuratif, dan rehabilitatif. Upaya kesehatan diselenggarakan guna menjamin tercapainya derajat kesehatan masyarakat setinggi-tingginya. Dalam hal pelayanan kesehatan meliputi pula pelayanan kesehatan berbasis masyarakat, di dalamnya termasuk pengobatan dan cara-cara tradisional yang terjamin keamanan dan khasiatnya. 


\section{Perumusan Masalah}

$\mathrm{M}$ asalah kesehatan terkait sosial budaya masyarakat nelayan menjadi permasalahan yang memerlukan suatu kajian lebih mendalam dan spesifik di setiap daerah dengan etnis tertentu. Wujud budaya dapat berupa suatu ide-ide, gagasan, nilai, norma, peraturan, dan lain sebagainya, yang sering diistilahkan sebagai adat istiadat. Wujud budaya yang lain berupa sistem sosial yaitu aktivitas serta tindakan berpola dari manusia dalam masyarakat. Wujud budaya bisa pula berupa bentuk benda atau hal-hal yang dapat dilihat, diraba, dan difoto yaitu hasil fisik dari aktifitas, perbuatan dan karya seperti alat sunat, alat penumbuk jamu, dan lain sebagainya. Wujud budaya tersebut merefleksikan budaya dan identitas sosial dari masyarakatnya. Pengembangan atau inovasi dengan pelibatkan sosial budaya lokal yang bermanfaat bagi upaya kesehatan sangat dibutuhkan untuk meningkatkan derajat kesehatan masyarakat tersebut melalui suatu intervensi yang dapat diterima oleh masyarakat pelakunya.

Mempersiapkan generasi penerus yang tangguh demi kesejahteraan bangsa Indonesia adalah tanggung jawab bersama, dan harus diprioritaskan pemeliharaan kesehatan sejak dalam kandungan sampai remaja. Permasalahan kesehatan seringkali merupakan masalah kesehatan yang lokal spesifik terkait dengan sosial budaya setempat yang perlu digali guna mengetahui permasalahan mendasar sehingga dapat segera dilakukan perbaikan atau diberdayakan bagi budaya yang berdampak positif bagi kesehatan. Dengan demikian kekayaan budaya Indonesia yang baik dapat terus dikembangkan, dilestarikan dan dimanfaatkan secara lokal bahkan bila memungkinkan secara nasional.

Pemahaman tentang budaya masyarakat nelayan terkait dengan masalah kesehatan sangat penting untuk diperhatikan sebagai faktor penentu menuju keberhasilan program-program kesehatan yang bertujuan meningkatkan kualitas hidup individu maupun masyarakat. Gambaran tersebut dapat dimanfaatkan para petugas kesehatan untuk mengetahui, mempelajari, dan memahami apa yang berlaku di masyarakat. Berdasar budaya yang sudah terpantau tersebut, program kesehatan dapat dirancang untuk meningkatkan status kesehatan ibu dan anak sesuai dengan permasalahan lokal spesifik. Dalam proses ini pendekatan budaya merupakan salah satu cara yang penting dan tidak bisa diabaikan.

Dari uraian di atas maka pertanyaan penelitian adalah bagaimana sistem pengetahuan masyarakat nelayan terhadap kesehatan ibu dan anak di Nagari Pasar Lama Muara Air Haji, Kecamatan Linggosari Baganti, Kabupaten Pesisir Selatan?

\section{Tujuan Penelitian}

$\mathrm{P}$ enelitian ini bertujuan untuk mengidentifikasi sistem pengetahuan masyarakat nelayan terhadap kesehatan ibu dan anak di Nagari Pasar Lama Muara Air Haji, Kecamatan Linggosari Baganti, Kabupaten Pesisir Selatan.

\section{Metodologi Penelitian}

okasi yang dipilih sebagai wilayah penelitian adalah di Nagari Pasar Lama Muara Air Haji, Kecamatan Linggosari Baganti, Kabupaten Pesisir Selatan. Lokasi ini dipilih karena berada di wilayah pesisir pantai Barat Sumatera yang memiliki lebih dari 1000 orang nelayan yang aktif dalam aktivitas perikanan dan kelautan.

Dalam penelitian ini menggunakan pendekatan penelitian kualitatif. Penelitian kualitatif memusatkan perhatian pada prinsip-prinsip umum yang mendasari perwujudan satuan-satuan gejala yang ada dalam kehidupan sosial. Dalam penelitian kualitatif yang dianalisis bukan variabelvariabel tetapi yang dianalisis dalam kaitan hubungan dengan prinsip-prinsip umum dari satuan-satuan gejala lainnya dengan menggunakan budaya masyarakat yang diteliti dan dari hasil analisis tersebut dianalisis lagi dengan menggunakan seperangkat teori yang berlaku (Neuman, 2006:149; Rudito, 2008: 78).

Teknik pengumpulan data yang telah dilakukan adalah menggunakan teknik observasi partisipasi, wawancara bebas dan mendalam dan studi kepustakaan. Pemilihan informan dengan situasi sosial tertentu, dengan sendirinya, perlu dilakukan secara purposif (bukan secara acak), yaitu atas dasar apa yang diketahui tentang 
variasi-variasi yang ada atau elemenelemen yang ada. Pemilihan informan yang purposif seperti yang dijelaskan di atas, juga dikenal istilah dengan teknik snowball sampling. Cara ini banyak dipakai ketika peneliti tidak banyak tahu tentang populasi penelitiannya. Peneliti hanya tahu satu atau dua orang yang berdasarkan penilaiannya bisa dijadikan informan. Karena peneliti menginginkan lebih banyak lagi, maka peneliti akan minta kepada informan pertama untuk menunjukan orang lain yang kira-kira bisa dijadikan informan.

Ada pun kriteria informan dalam penelitian ini adalah:

- Petugas Kesehatan seperti bidan, kader kesehatan

- Tokoh masyarakat seperti wali nagari beserta staf pemerintahan nagari.

Data-data yang telah dikumpulkan oleh peneliti termasuk juga catatan lapangan dikelompokkan oleh peneliti atas dasar aktivitas khusus yang ada dan diteliti. Kemudian dari pengelompokkan data tersebut, data-data itu kemudian diabstraksikan dan dikaitkan satu dengan lainnya sebagai satu kesatuan kejadian dan fakta yang terintegrasi. Dari abstraksi tersebut maka akan tampak pranata sosial yang berlaku di wilayah atau komuniti tersebut (Bungin, 2004:60). Dalam menganalisis tentunya selalu terkait dengan konsep yang telah dipelajari sebelumnya. Sehingga dari hasil analisis akan tampak kesesuaian dari data yang diperolehnya dengan konsep yang dipelajarinya atau akan berbeda dengan konsep yang dipelajarinya karena masalah sosial akan selalu berbeda antara satu masyarakat dengan masyarakat lainnya. Setelah itu disusun sesuai dengan kategori-kategori dan kemudian disimpulkan. Apabila dalam kesimpulan masih menimbulkan keraguan maka dilakukan pengkategorian ulang hingga seluruh data yang telah berhasil dikumpulkan dianggap sesuai dengan tujuan penelitian. Temuan di lapangan akan diolah dengan data yang didapat dari literatur dan akan disajikan dalam suatu karya etnografi deskriptif.

\section{KAJIAN PUSTAKA}

$\mathrm{K}$ esehatan merupakan bagian integral dari kebudayaan. Manusia mampu melakukan aktifitas kebudayaan jika dalam keadaan sehat, sehingga dapat dipahami bahwa kesehatan merupakan elemen penting bagi kebudayaan. Begitu pula sebaliknya, kebudayaan juga bisa menjadi pedoman masyarakat dalam memahami kesehatan. Untuk itu, memahami masalah kesehatan yang ada di masyarakat melalui kebudayaan sangat penting dilakukan, karena masalah kesehatan tidak pernah lepas dari situasi dan kondisi masyarakat dan budayanya (Ahimsa, 2005:16).

Sebagai contoh, dalam penelitian "Hambatan Budaya dalam Interaksi BidanIbu Hamil: Studi Ketaatan untuk Meningkatkan Suplemen dan Status Besi di Puskesmas Banyuurip, Kabupaten Purworejo, Jawa Tengah" yang dilakukan oleh Emiliana Mariyah dan Mohammad Hakimi (2005:105). Dalam penelitian tersebut Emiliana dan Hakimi (2005:132) menyimpulkan bahwa masih kuatnya sistem kepercayaan dan praktek pantangan yang dilakukan ibu hamil. Pada saat hamil, secara medis ibu dan bayi memerlukan makanan yang bergizi dan zat besi lebih banyak. Namun dalam praktek, yang terjadi sebaliknya. Ibu menghindari bahkan mengurangi jumlah dan jenis makanan tertentu yang mengandung gizi tinggi, serta mengabaikan zat besi yang sangat dibutuhkan selama kehamilan, karena berbagai alasan yang berkaitan dengan nilai budaya setempat dan kepercayaan. Berdasarkan penjelasan sekilas mengenai penelitian tersebut, dapat dipahami bahwa kesehatan mempunyai korelasi yang sangat erat dengan kebudayaan. Untuk itu, perlu adanya pemahaman mengenai kebudayaan untuk memahami kondisi kesehatan suatu masyarakat.

Mengutip pandangan Heddy Shri Ahimsa-Putra (2005:16), bahwa dalam pandangan para ilmuan sosial budaya, masalah kesehatan dalam suatu masyarakat sangat erat kaitannya antara fasilitas kesehatan, sarana transportasi dan komunikasi yang ada dalam suatu masyarakat, dengan kepercayaan, jenis mata pencaharian serta lingkungan fisik tempat masyarakat tersebut berada Dilihat 
dari perspektif ini masalah kesehatan tidak lagi dapat dipahami dan diatasi hanya dengan memusatkan perhatian pada kesehatan tubuh. Kesehatan tubuh adalah hasil dari proses interaksi antara unsurunsur internal tubuh dengan unsur eksternalnya. Kalau para dokter lebih banyak memperhatikan unsur-unsur internal, para ilmuwan sosial budaya lebih memperhatikan unsur-unsur eksternal.

Selain mengeksplorasi unsur-unsur budaya yang berkaitan dengan kesehatan, akan di pelajari juga peran pelayanan kesehatan konvensional dalam mempengaruhi perilaku sehat untuk meningkatkan status kesehatan melalui tingkat pengetahuan yang dimiliki. Pengetahuan merupakan hasil dari tahu, dan ini terjadi setelah orang melakukan pengindraan terhadap suatu objek tertentu. Pengindraan terjadi melalui pancaindra manusia, yakni indra penglihatan, pendengaran, penciuman, rasa, dan raba. Sebagian besar pengetahuan manusia diperoleh melalui mata dan telinga (Notoatmodjo, 2007). Secara garis besarnya dibagi ke dalam 6 tingkat pengetahuan, yakni (1) Tahu, (2) Memahami, (3) Aplikasi, (4) Analisis, (5) Sistesis dan (6) Evalusi. Pengetahuan terdiri atas kepercayaan tentang kenyataan (reality). Salah satu cara untuk mendapatkan dan memeriksa pengetahuan adalah dari tradisi atau dari yang berwenang di masa lalu yang umumnya dikenal, seperti aristoteles. Pengetahuan juga mungkin diperoleh berdasarkan pengumuman sekuler atau kekuasaan agama, negara, atau gereja. Cara lain untuk mendapat pengetahuan dengan pengamatan dan eksperimen: metode ilmiah. Pengetahuan juga diturunkan dengan cara logika secara tradisional, otoratif atau ilmiah atau kombinasi dari mereka, dan dapat atau tidak dapat dibuktikan dengan pengamatan dan pengetesan. Pengetahuan atau kognitif merupakan dominan yang sangat penting dalam membentuk tindakan seseorang (overt behavior). Dari pengetahuan dan penelitian ternyata prilaku yang didasari pengetahuan akan lebih langgeng dari pada prilaku yang tidak didasari oleh pengetahuan (Notoatmodjo, 2010).

\section{PEMBAHASAN HASIL PENELITIAN 3.1 Gambaran Lokasi Penelitian}

agari ${ }^{4}$ Pasar Lama Muara Air Haji
terletak di Kecamatan Linggosari
Baganti, Kabupaten Pesisir Selatan, Sumatera Barat. Nagari Pasar Lama Muara Air Haji terdiri dari 2 jorong ${ }^{5}$, yang terdiri: Jorong Kampung Pasar Lama dan Jorong Kampung Muara Air Haji. Jumlah jorong yang berada di daerah pesisir sebanyak 1 buah (45\%) dan 1 jorong bukan pesisir (55\%), dengan jumlah penduduk pesisir dengan mata pencaharian sebagai nelayan sebanyak 59 KK. Batas wilayah administrasi Pemerintahan Nagari Pasar Lama Muara Air Haji adalah:

a) Sebelah Utara berbatasan dengan Pemerintah Nagari Punggasan.

b) Sebelah Selatan berbatasan dengan Pemerintah Nagari Air Haji Barat.

c) Sebelah Barat berbatasan dengan Samudera Indonesia.

d) Sebelah Timur berbatasan dengan Pemerintahan Nagari Air Haji.

Nagari Nagari Pasar Lama Muara Air Haji terletak pada 10052 - 1017 BT dan 1 49, 53 - 1 Lintang selatan. Nagari ini memiliki ketinggian dari permukaan laut lebih kurang $2,5 \mathrm{~m}$ sampai dengan $7 \mathrm{~m}$, suhu udara maksimum $31{ }^{\circ} \mathrm{C}$ dan suhu minimum $20{ }^{\circ} \mathrm{C}$ dengan curah hujan dan jumlah hari hujan pada Oktober 2010 ini rata-rata $308 \mathrm{~m} /$ bulan dan 17 hari/bulan. Wilayah ini terdiri dari dataran rendah, dengan tinggi pesisir pantai yang rendah. Penggunaan lahan dan luas wilayah secara terperinci dapat dilihat pada tabel berikut ini:

\footnotetext{
${ }^{4}$ Nagari sendiri berasal dari bahasa Sansekerta, dalam bahasa Indonesia berarti kota (ibu kota), istana dan negara atau kerajaan sehingga Minangkabau nagari sering disebut dengan "republik kecil". Nagari adalah pembagian wilayah administratif di propinsi Sumatera Barat di bawah kecamatan yang dipimpin oleh seorang wali nagari.

5 Jorong adalah satu kesatuan di dalam masyarakat yang tinggal di suatu daerah tertentu. Setiap jorong memiliki pemimpin yang disebut wali Jorong yang berada di bawah pemerintahan nagari.
} 
Tabel 1. Penggunaan Lahan dan Luas Wilayah di Pasar Lama Muara Air Haji

\begin{tabular}{|l|c|c|}
\hline \multicolumn{1}{|c|}{ Penggunaan Lahan } & Luas Wilayah & Persentase \\
\hline Perumahan dan Pekarangan & $18 \mathrm{Ha}$ & $1 \%$ \\
\hline Sawah teririgasi & $358 \mathrm{Ha}$ & $15 \%$ \\
\hline Sawah tadah hujan & $62 \mathrm{Ha}$ & $3 \%$ \\
\hline Perkebunan & $804 \mathrm{Ha}$ & $32 \%$ \\
\hline Hutan Negara & $1224 \mathrm{Ha}$ & $49 \%$ \\
\hline JUMLAH & $2466 \mathrm{Ha}$ & $100 \%$ \\
\hline
\end{tabular}

Sumber: Profil Pasar Lama Air Haji, 2013

Berdasarkan penggunaan lahan dan luas wilayah tersebut diatas menjelaskan bahwa penggunaan lahan hutan negara dan lahan persawahan yang memiliki aliran irigasi mendominasi luas wilayah di Pasar Lama Muara Air Haji terletak di Kecamatan Linggosari Baganti, Kabupaten Pesisir Selatan. Nagari Pasar Lama Muara Air Haji memiliki garis pantai yang cukup panjang dan juga memiliki keindahan dari aspek pemandangan lautnya.

\subsection{Sejarah Nagari}

$\mathrm{B}$ erdasarkan hasil wawancara dengan Bapak Amardi (Sekretaris Nagari) bahwa Nama Nagari Pasar Lama Muara Air Haji menurut cerita yang berkembang dan diyakini di tengah-tengah masyarakat bahwa menurut sejarah bermula dari tapian aie (pinggiran sungai) di hulu Sungai Lubuk Pakih. Di tapian air tersebut, tinggalh seorang yang baik hati bernama "Aji". Karena tempatnya yang landai serta airnya yang jernih menjadi daya tarik bagi kebanyakan orang untuk datang dan mandi di tapian itu. Bergitu digemarinya tapian itu, masyarakat menamakannya sebutan "Air Haji”. Karena kemurahan hari si Aji tersebut, masyarakat diperbolehkan untuk tinggal dan membuat rumah di dekat tapian tersebut sehingga tapian tersebut menjadi ramai dan berkembang menjadi sebuah perkampungan yang mereka namakan dengan "Aia Haji". Seiring dengan perubahan zaman, kampung terebut berkembang menjadi sebuah nagari yang disebut dengan Air Haji.

Seiring dengan itu dinamika penyelenggaraan Pemerintahan Nagari menunjukkan bahwa percepatan pelayanan publik yang efektif dan efisien merupakan kebutuhan bagi masyarakat. $\mathrm{Hal}$ ini ditunjukkan dengan munculnya aspirasi masyarakat yang menghendaki dilakukannya pemekaran terhadap Pemerintahan Nagari yang sudah ada menjadi beberapa Pemerintahan Nagari baru.

Lahirnya Pemerintahan Nagari Pasar Lama Muara Air Haji merupakan bentuk kebijakan pemerintah daerah untuk menyikapi aspirasi masyarakat yang menginginkan dimekarkannya Pemerintahan Nagari Air Haji (Pemerintahan Nagari awal) menjadi 9 (Sembilan ) Pemerintahan Nagari yaitu :

a) Pemerintahan Nagari Pemerintahan Nagari Air Haji;

b) Pemerintahan Nagari Air Haji Tenggara:

c) Pemerintahan Nagari Pasar Lama Muara Air Haji;

d) Pemerintahan Nagarai Air Haji Barat;

e) Pemerintahan Nagari Pasar Bukit Air Haji;

f) Pemerintahan Nagari Air Haji Tengah;

g) Pemerintahan Nagari Rantau Simalenang Air Haji;

h) Pemerintahan Nagari Muara Gadang Air Haji;

i) Pemerintahan Nagari Sungai Sirah Air Haji.

Atas dasar itulah Pemerintah Daerah bersama Dewan Perwakilan Rakyat Daerah (DPRD) merespon aspirasi dan keinginan masyarakat Nagari Air Haji dengan melakukan kajian teknis, administratif dan melalui tahapan pembahasan sesuai dengan ketentuan perundang-undangan. Suatu penekanan penting yang perlu dipahami bahwa tindakan memekarkan Pemerintahan Nagari yang sudah ada sebagai wilayah penyelenggaraan urusan pemerintahan tidak diikuti dengan melakukan pemekaran Kerapatan Adat Nagari (KAN) sebagai wilayah kesatuan hukum adat. Pemekaran pemerintahan nagari pada prinsipnya hanya melakukan pembagian wilayah penyelenggaraan urusan pemerintahan 
guna mempersingkat rentang kendali pelayanan sehingga diharapkan mampu meningkatkan kualitas pelayanan publik dan mempercepat terwujudnya kesejahteraan masyarakat

Berdasarkan Peraturan daerah Kabupaten Pesisir Selatan Nomor 75 tahun 2011 tentang pembentukan pemerintahan nagari Pasar Lama Muara Air Haji di Kecamatan Linggo Sari Baganti yang telah disahkan pada tanggal 30 Juni 2011, maka Pemekaran Pemerintahan Nagari adalah tindakan memekarkan Pemerintahan Nagari dari 1 (satu) Pemerintahan Nagari awal menjadi 2(dua) atau lebih Pemerintahan
Nagari baru, yang sebelumnya masuk dalam pemerintahan Nagari Air Haji.

\subsection{Keadaan Demografi}

B erdasarkan data kependudukan Nagari Pasar Lama Muara Air Haji tahun 2013, jumlah penduduk sebanyak 2.798 jiwa orang, dengan penduduk laki-laki berjumlah 1.349 jiwa dan penduduk perempuan 1.449 jiwa orang. Jumlah kepala keluarga (KK) adalah 735 . Untuk lebih jelasnya mengenai komposisi penduduk Nagari Pasar Lama Muara Air Haji berdasarkan tingkat umur dapat dilihat dalam tabel dibawah ini.

Tabel 2. Komposisi Penduduk dan Tingkat Umur di Nagari Pasar Lama Muara Air Haji Berdasarkan Jenis Kelamin

\begin{tabular}{|c|l|c|}
\hline No. & \multicolumn{1}{|c|}{ Uraian } & Jumlah \\
\hline 1 & Kependudukan & \\
\hline & A.Jumlah Penduduk (Jiwa) & 2.798 \\
\hline & B. Jumlah KK & 735 \\
\hline & C. Jumlah laki-laki & 1.349 \\
\hline & a. $0-15$ tahun & 275 \\
\hline & b. $16-59$ tahun & 839 \\
\hline & c. Diatas 60 tahun & 235 \\
\hline & D. Jumlah perempuan & 1.449 \\
\hline & a. $0-15$ tahun & 280 \\
\hline & b. $16-59$ tahun & 954 \\
\hline & c. Diatas 60 tahun & 215 \\
\hline
\end{tabular}

Berdasarkan hasil wawancara diperoleh bahwa jumlah penduduk terbanyak di Nagari Pasar Lama Muara Air Haji yang dikategorikan pada usia produktif berada pada tingkat umur antara 20 tahun hingga 50 tahun. Hal tersebut terkait erat dengan berbagai pekerjaan yang ditekuni oleh masyarakat di Nagari Pasar Lama Muara Air Haji.

\subsubsection{Mata Pencaharian}

$\mathrm{D}$ alam pemenuhan kebutuhan hidup masyarakat di Nagari Pasar Lama Muara Air Haji, baik kebutuhan dasar seperti kebutuhan sandang, pangan dan papan maupun kebutuhan sekunder seperti kebutuhan pendukung lainnya sangat diperlukan mata pencaharian untuk mencapai usaha tersebut. Dalam pemenuhan kebutuhan tersebut, di dalam masyarakat mempunyai mata pencaharian yang beragam/bervariasi. Demikian juga dengan masyarakat Nagari Pasar Lama Muara Air Haji yang memiliki beragam mata pencaharian. Berikut ini data mengenai persentase penduduk berdasarkan variasi mata pencaharian di Nagari Pasar Lama Muara Air Haji. 
Tabel 3. Jumlah Penduduk Nagari Pasar Lama Muara Air Haji Menurut Mata Pencaharian

\begin{tabular}{|c|l|c|c|}
\hline No. & \multicolumn{1}{|c|}{ Jenis Mata Pencaharian } & Jumlah & $\%$ \\
\hline 1 & Petani & 44 & 5 \\
\hline 2 & Buruh & 245 & 29 \\
\hline 3 & Nelayan & 59 & 7 \\
\hline 4 & Pedagang & 40 & 5 \\
\hline 5 & Jasa & 15 & 2 \\
\hline 6 & PNS/ABRI & 20 & 2 \\
\hline 7 & Tidak Bekerja & 421 & 50 \\
\hline \multicolumn{2}{|l}{ JUMLAH } & 844 & 100 \\
\hline
\end{tabular}

Sumber: Profil Pasar Lama Air Haji, 2013

Berdasarkan tabel diatas menunjukkan bahwa sebagian besar penduduk di Nagari Pasar Lama Muara Air Haji bermata pencaharian sebagai petani, buruh dan nelayan, terutama nelayan buruh sebanyak 59 (7\%). Di samping, persentase masyarakat yang tidak bekerja di nagari tersebut cukup tinggi (50\%). Hal ini menyebabkan wilayah ini rawan terhadap tindakan kriminal dan tingkat keamanan rendah. Kondisi ini juga diperkuat dengan wilayah yang merupakan lintas jalan yang menghubungkan antara propinsi Sumatera Barat dengan propinsi Bengkulu.

\subsubsection{Tingkat Pendidikan}

$\mathrm{P}$ endidikan merupakan kebutuhan utama masyarakat di Nagari Pasar Lama Muara Air Haji sebagai usaha untuk menambah ilmu pengetahuan mereka dan juga mengangkat pada derajat yang lebih tinggi. Kesadaran masyarakat di Nagari Pasar Lama Muara Air Haji terhadap pentingnya pendidikan cukup tinggi dimana sebagian besar masyarakatnya sudah mengenyam pendidikan padan tingkat SMP dan SMA. Meskipun demikian, sebagian masyarakatnya juga ada yang menamatkan pendidikan hanya pada tingkat SD. Hal tersebut dapat dilihat pada data tingkat pendidikan di Nagari Pasar Lama Muara Air Haji berikut ini:

Tabel 4. Jumlah Penduduk Nagari Pasar Lama Muara Air Haji Menurut Tingkat Pendidikan

\begin{tabular}{|c|l|c|c|}
\hline No. & \multicolumn{1}{|c|}{ Tingkat Pendidikan } & Jumlah & $\%$ \\
\hline 1 & Tidak Tamat SD & 230 & 25 \\
\hline 2 & SD/Sederajat & 350 & 39 \\
\hline 3 & SMP/Sederajat & 166 & 18 \\
\hline 4 & SMA/Sederajat & 145 & 17 \\
\hline 5 & Akademi/Perguruan Tinggi & 12 & 1 \\
\hline \multicolumn{2}{|c|}{ JUMLAH } & 903 & 100 \\
\hline
\end{tabular}

Sumber: Profil Pasar Lama Air Haji, 2013

Berdasarkan data tersebut diatas menunjukkan bahwa tingkat pendidikan di Nagari Pasar Lama Muara Air Haji terbilang masih rendah. Hal tersebut diperlihatkan melalui jumlah penduduk yang telah menamatkan pendidikan sebagian besar adalah tamat SD (39\%), diikuti SMP (18\%) dan SMA (17\%) dan perguruan tinggi sebanyak 12 (1\%). Meskipun demikian, diperoleh juga terdapat penduduk yang tidak menamatkan pendidikan SD (25\%). Pada umumnya, mereka yang tidak menamatkan pendidikan SD dikarenakan faktor ekonomi dan kesempatan.

Hasil pembangunan di bidang pendidikan di Nagari Pasar Lama Muara Air Haji masih belum mengembirakan. Akses masyarakat terhadap pendidikan masih belum mencapai target yang diinginkan. Pada 2007, akses pendidikan bagi anak usia sekolah dasar dan lanjutan pertama (umur 7-15 tahun) baru mencapai sekitar $50 \%$. Dengan demikian masih terdapat $13 \%$ anak usia sekolah lanjutan pertama di daerah ini yang belum mendapat 
pendidikan. Hal ini disebabkan antara lain karena sarana pendidikan relatif jauh dari kampung; beban ekonomis sekolah yang semakin berat; dan kondisi ekonomi keluarga

yang semakin susah. Tingkat kemampuan tulis baca masyarakat juga masih belum memuaskan. Pada 2013, angka melek huruf orang dewasa (umur 15 tahun ke atas) di Pesisir Selatan sekitar 91,2\%. Artinya, pada kalangan penduduk dewasa di nagari ini masih terdapat sebesar $8,8 \%$ yang belum bisa tulis baca huruf latin. Di samping itu, mutu pendidikan ternyata juga masih tertinggal dibandingkan daerah lain di Sumatera Barat. Hal ini disebabkan oleh, antara lain, rendahnya kompetensi guru, kurangnya fasilitas pembelajaran, dan rendahnya partisipasi orang tua terhadap pendidikan anak-anaknya.

Untuk menunjang aktivitas pendidikan masyarakat di Nagari Pasar Lama Muara Air Haji sangat dibutuhkan sarana dan prasarana agar tujuan pendidikan dapat tercapai. Adapun sarana pendidikan yang terdapat di Nagari Pasar Lama Muara Air Haji dapat dilihat pada tabel berikut ini:

Tabel 5. Sarana Pendidikan di Nagari Pasar Lama Muara Air Haji

\begin{tabular}{|c|l|c|}
\hline No. & \multicolumn{1}{|c|}{ Sarana Pendidikan } & Jumlah \\
\hline 1 & Taman Kanak-Kanak (TK) & 1 \\
\hline 2 & Sekolah Dasar (SD) & 2 \\
\hline 3 & Sekolah Menengah Pertama (SMP) & - \\
\hline 4 & Sekolah Menengah Atas (SMA) & - \\
\hline 5 & Akademi/Perguruan Tinggi & 4 \\
\hline \multicolumn{2}{|r|}{ JUMLAH } \\
\hline
\end{tabular}

Sumber: Profil Pasar Lama Air Haji, 2013

Berdasarkan tabel diatas menunjukkan bahwa jumlah sarana pendidikan di Nagari Pasar Lama Muara Air Haji kurang memadai dengan tersedianya sarana pendidikan SD dan SMA. Hal tersebut memperlihatkan tingkat pendidikan masyarakat belum merata dan terbilang masih rendah dikarenakan fasilitas pendidikan kurang memadai.

\subsubsection{Sarana Kesehatan}

Pelayanan

$\mathrm{K}$ ondisi sarana pelayanan kesehatan di Nagari Pasar Lama Muara Air Haji dianggap cukup memadai. Dengan fasilitas Puskesmas dan Pustu sebanyak 1 unit, masyarakat terutama para ibu menggunakan pelayanan kesehatan Di nagari Pasar Lama Muara Air Haji, biasanya ibu-ibu antusias mengikuti kegiatan posyandu. Sejak ada bidan di nagari ini, tidak ada lagi ibu-ibu melahirkan anak meninggal. Adanya lembaga kesehatan berupa Polindes membuat kesehatan warga nagari ini meningkat. Polindes tidak saja tempat pelayanan bagi ibu hamil dan bersalin, tetapi juga sebagai sarana untuk pelayanan kesehatan secara umum bagi warga nagari ini.

\subsection{Pola Pemukiman Nagari Pasar Lama Muara Air Haji}

ola pemukiman adalah wujud dari bentuk pemukiman pada suatu daerah yang meliputi pola letak tempat tinggan dan bentuk rumah di pemukiman tersebut. Pola letak pemukiman di Nagari Pasar Lama Muara Air Haji tidak berbeda jauh dengan pola pemukiman wilayah pesisir di daerah lain, dimana rumah-rumah membentang sepanjang pantai di pesisir pantai Air Haji.

Pola pemukiman Nagari Pasar Lama Muara Air Haji yang mengikuti garis pantai dimulai dari Jorong Kampung Muara Air Haji, kemudian dilanjutkan menuju Jorong Kampung Pasar Lama. Untuk menuju Nagari tersebut, dapat ditempuh dengan kendaraan beroda dua dan empat dengan sarana jalan yang cukup baik sehingga dapat ditempuh selama 4 jam perjalanan dari ibu kota Sumatera Barat, yaitu kota Padang.

Kepemilikan rumah yang berada di sekitar pantai adalah sebagian besar dimiliki oleh rumah tangga nelayan buruh dan juga pedagang ikan berskala kecil. Pada umumnya, bentuk rumah di Nagari Pasar Lama Muara Air Haji, terutama kampungkampung di sekitar pantai terdiri dari rumah 
tidak permanen dan semi permanen dan hanya beberapa rumah saja yang permanen, yaitu sekitar 5-10 rumah. Untuk rumah-rumah yang berada di sekitar jalan utama yang menghubungkan antar jorong di Nagari Pasar Lama Muara Air Haji, keadaannya lebih baik dari rumah yang ada di dekat pantai. Biasanya rumah-rumah di wilayah ini dihuni oleh pedagang ikan dengan skala yang lebih besar dibandingkan dengan pedagang yang ada di pinggir pantai.

Berdasarkan observasi (melalui pengamatan), terdapat beberapa rumah di pemukiman sekitar wilayah pantai (5-10 rumah) yang dihuni oleh para nelayan yang tidak layak untuk menjadi tempat tinggal. Rumah mereka hanya beralaskan pasir pantai dan berdindingkan kayu dan juga atapnya terbuat dari seng yang sudah berkarat dan berlubang.

Di sekitar pemukiman nelayan, terdapat 2-4 warung makanan yang selalu dipenuhi oleh para nelayan buruh, terutama sekali ketika mereka sudah selesai melaksanakan aktivitas penangkapan ikan seperti memukat dan juga pada saat terjadinya badai (cuaca tidak baik). Aktivitas yang biasa mereka lakukan adalah berdiskusi tentang aktivitas penangkapan ikan, bermain domino/kartu dan hanya sekedar minum kopi.

\subsection{Aktivitas Sosial Budaya Masyarakat}

$\mathrm{M}$ asyarakat di Nagari Pasar Lama Muara Air Haji hampir seluruhnya beragama Islam, hanya $0,01 \%$ saja yang non-muslim. Dengan demikian, ketersediaan sarana dan prasarana ibadah, masjid dan mushalla, menjadi keharusan untuk kenyamanan mereka dalam menjalankan ibadah.

Sebagai orang Minangkabau yang menganut sistem matrilineal, Masyarakat di Nagari Pasar Lama Muara Air Haji pada umumnya berasal dari Kabupaten Solok dan Solok Selatan, seperti Muaralabuh, Muaropaneh, Koto Anau, Sungai Pagu, Alahan Panjang, Lubuk Sikarah, Lubuk Gadang dan sebagainya. Oleh karena itu, secara sosial budaya penduduk daerah ini masih mempunyai hubungan dengan beberapa nagari di Solok dan Solok Selatan.

Oleh karena itu, sistem pemilikan dan penguasaan tanah di daerah ini tunduk kepada Hukum Adat Minangkabau yang mengenal tanah pusako dan ulayat (nagari), dengan kepemimpinan adat tungku tigo sajarangan (ninik mamak, ulama dan cerdik pandai). Pada masa kolonial, daerah ini juga pernah didiami oleh etnis non-Minangkabau seperti Cina, Jawa, Bugis, Batak, Aceh dan Muko-muko. Pada umumnya mereka telah membaur dengan kehidupan sosial budaya orang Minangkabau. Namun, sekarang tidak lagi etnis Cina yang menjadi Masyarakat di Nagari Pasar Lama Muara Air Haji.

Partisipasi dalam pembangunan di daerah ini sangat tinggi. Hampir semua sarana dan prasarana publik dibangun di atas tanah adat yang diserahkan oleh masyarakat hukum adat baik tanah pusako maupun tanah ulayat nagari. Potensi ini bisa menjadi keunggulan bagi daerah ini dalam pengadaan tanah untuk pembangunan. Sebagaimana lazimnya orang Minang, masyarakat Pesisir Selatan juga terkenal dengan budaya lisan. Hal ini melahirkan jenis kesenian anak nagari yang populer di daerah ini yaitu kesenian lisan Rabab Pasisie yang menggunakan biola dan nyanyian vokal. Sementara itu, seni bela diri Pencak Silat juga berkembang baik di daerah ini.

\subsection{Masalah Kesehatan: Proses Kehamilan dan Melahirkan}

$\mathrm{P}$ ermasalahan utama yang saat ini masih dihadapi berkaitan dengan kesehatan ibu di Indonesia adalah masih tingginya angka kematian ibu yang berhubungan dengan persalinan. Perawatan kehamilan merupakan salah satu faktor yang amat perlu diperhatikan untuk mencegah terjadinya komplikasi dan kematian ketika persalinan, disamping itu juga untuk menjaga pertumbuhan dan kesehatan janin. Memahami perilaku perawatan kehamilan (ante natal care) adalah penting untuk mengetahui dampak kesehatan bayi dan si ibu sendiri. Di kalangan masyarakat, masih banyak ibu-ibu yang menganggap kehamilan sebagai hal yang biasa, alamiah dan kodrati. Mereka merasa tidak perlu memeriksakan dirinya secara rutin ke bidan ataupun dokter.

Masih banyaknya ibu-ibu yang kurang menyadari pentingnya pemeriksaan kehamilan menyebabkan tidak terdeteksinya faktor-faktor resiko tinggi yang mungkin 
dialami oleh mereka. Resiko ini baru diketahui pada saat persalinan yang sering kali karena kasusnya sudah terlambat dapat membawa akibat fatal yaitu kematian. Hal ini kemungkinan disebabkan oleh rendahnya tingkat pendidikan dan kurangnya informasi Permasalahan lain yang cukup besar pengaruhnya pada kehamilan adalah masalah gizi. Hal ini disebabkan karena adanya kepercayaan-kepercayaan dan pantangan- pantangan terhadap beberapa makanan. Sementara, kegiatan mereka sehari-hari tidak berkurang ditambah lagi dengan pantangan-pantangan terhadap beberapa makanan yang sebenamya sangat dibutuhkan oleh wanita hamil tentunya akan berdampak negatif terhadap kesehatan ibu dan janin. Tidak heran kalau anemia dan kurang gizi pada wanita hamil cukup tinggi terutama di daerah pedesaan.

Memasuki masa persalinan merupakan suatu periode yang kritis bagi para ibu hamil karena segala kemungkinan dapat terjadi sebelum berakhir dengan selamat atau dengan kematian. Sejumlah faktor memandirikan peranan dalam proses ini, mulai dari ada tidaknya faktor resiko kesehatan ibu, pemilihan penolong persalinan, keterjangkauan dan ketersediaan pelayanan kesehatan, kemampuan penolong persalinan sampai sikap keluarga dalam menghadapi keadaan gawat.

Berdasarkan hasil penelitian diketahui bahwa pemeriksaan hamil dan melahirkan oleh informan dilakukan pada bidan. Setiap kehamilan seorang perempuan melakukan pemeriksaan sebanyak $4 x$. Salah satu informan pernah mengalami keguguran pada hamil ke 4, dimana menurut informan, masalah keguguran dikarenakan demam tasapo. Biasanya waktu usia kehimilannya telah memasuki usia 3 bulan. Tak lama setelah keguguran informan akan hamil lagi. Tetapi janin yang dikandungnya itu tidak sehat sehingga meninggal di dalam kandungan ketika itu usia kehamilannya sudah 8 bulan. Menurut salah satu informan bahwa pada masuk bulan ke 8 perutnya mengalami penyusutan. Setelah diperiksa ke bidan ternyata kata bidan bayinya sudah meninggal. Pada waktu melahirkan itu ia mengalami pendarahan selama semalaman.

Dalam perawatan kehamilan, informan banyak memperoleh pengetahuan dari bidan dan tidak banyak mendapat pengetahuan tentang kehamilannya dari dukun beranak. Menurut salah satu informan yang berhasil diwawancarai, saat ini tidak ada lagi dukun beranak di nagari tersebut. Hampir semua ibu hamil memeriksakan kehamilannya ke bidan atau polindes. Akan tetapi, tetapi informan dan ibu-ibu hamil lainnya di nagari itu melakukan pengurutan kehamilannya yang tujuannya untuk memperbaiki letak janin agar mudah melahirkan.

\subsection{Masalah Kesehatan Anak: Perawatan Anak}

S ebagian besar informan yang berhasil diwawancarai mengakui bahwa semua anaknya sejak bayi hingga balita selalu dibawa ke Posyandu. Semua anaknya mendapatkan imunisasi lengkap, dan menurut pengakuan informan tidak ada masalah dengan imunisasi pada anakanaknya dan malah mereka jarang sakit.

Di nagari Pasar Lama Muara Air Haji, biasanya ibu-ibu antusias mengikuti kegiatan posyandu. Kegiatan Posyandu dihadiri lebih kurang 50 keluarga setiap bulannya. Ibu-ibu akan rajin datang apabila ada adanya program PKH (Pendidikan Keluarga harapan. Program ini berupa bantuan dana pendidikan yang masingmasing keluarga tidak sama jumlahnya. Besar dana yang diterima berdasarkan jumlah anak yang sekolah, rata-rata berkisar Rp 700 ribu hingga Rp 1 juta per keluarga. Mereka terima $4 x$ dalam satu tahun. Program ini telah berjalan sejak tahun 2007.

Selain itu, peran kader Posyandu juga gigih mengajak ibu-ibu untuk mengikuti kegiatan tersebut. Malah tidak jarang kader Posyandu menjemput iibu-ibu yang tidak datang membawa bayi dan balitanya ke kegiatan Posyandu. Sebagai kader Posyandu sebagai salah seorang informan, sebenarnya informan tidak mendapatkan bayaran honor yang layak. la mengatakan memperoleh honor sebanyak Rp 25 ribu setiap satu bulan yang ia terima pertiga bulan. Namun, ia mengatakan ia senang melakukan pekerjaannya tersebut.

Ketika kegiatan di Posyandu berlangsung diperoleh anak-anak yang mengalami gizi kurang tetapi tidak banyak, yakni sebanyak 3 balita yang berasal dari 2 keluarga. Satu dari keluarga ini memiliki 
anak kembar dan anak kembar tersebut tercatat sebagai anak yang mengalami gizi kurang.

Kematian anak tidak ditemukan di nagari ini sekarang. Sejak ada bidan di nagari ini kira-kira sejak 22 tahun lalu, tidak ada lagi ibu-ibu melahirkan anak meninggal. Adanya lembaga kesehatan berupa Polindes membuat kesehatan warga nagari ini meningkat. Polindes tidak saja tempat pelayanan bagi ibu hamil dan bersalin, tetapi juga sebagai sarana untuk pelayanan kesehatan secara umum bagi warga nagari ini. Di Polindes masyarakat berobat tidak membayar jika mereka berobat sebelum jam 12 siang. Lewat dari jam tersebut baru mereka, tetapi masyarakat tidak keberatan karena bayarannya masih terjangkau oleh mereka.

Menurut keterangan informan sejak bidan desa sudah dikenal masyarakat tidak ada lagi ibu-ibu hamil yang melahirkan ke dukun. Sekarang ini dukun beranak tidak ditemukan lagi di nagari ini. Namun begitu masih ada ibu-ibu hamil yang melakukan perawatan kehamilan ke dukun, yaitu dukun urut. Mereka mengurut kandungannya dengan tujuan untuk memperbaiki letak janin agar mudah melahirkan. Biasanya mereka melakukan itu ketika sudah mau melahirkan.

\subsection{Perilaku Masyarakat terhadap Kesehatan}

$\mathrm{P}$ erilaku masyarakat berkaitan dengan kesehatan terutama untuk perawatan kehamilan dan mengobati penyakit yang di derita sudah mulai baik. Sebagian besar para ibu di nagari Pasar Lama Muara Air Haji sudah merawat kehamilan seperti yang dianjurkan kesehatan modern melalui pendidikan yang diberikan bidan desa. Begitu juga dengan persalinan yang telah mereka lakukan di bidan atau rumah sakit. Akan tetapi, masih ditemukan perilaku kesehatan yang masih kurang baik, seperti penggunaan air bersih masih menggunakan sumur gali dan air sungai. Kemudian buang air besar masih ada yang melakukannya di tepi pantai. Demikian juga dalam hal membuang sampah, menurut informan masyarakatnya membuang sampah ke pinggir pantai. Hal ini tentu bukan suatu baik karena dapat mencemari laut bila sampah terbawa ombak ke dalam laut.
Walaupun pelayanan kesehatan modern sudah menjadi bagian kehidupan masyarakat ini dalam merawat kesehatan mereka. Akan tetapi, mereka tetap masih mneggunakan pengobatan tradisonal dalam mengobati penyakit-penyakit tertentu, terutama penyakit yang etiologinya berasal dari supra natural. Seperti yang dikatakan informan yaitu penyakit tasapo. Maka untuk penyakit ini mereka menggunakan ramuan yang berasal dari daun pohon jua.

\section{KESIMPULAN DAN SARAN 1. Kesimpulan}

$\mathrm{D}$ ari penelitian ini dapat disimpulkan bahwa tingkat pengetahuan para ibu dalam masalah kesehatan ibu dan anak sudah cukup tinggi. Tingginya tingkat pengetahuan dan didukung oleh tingkat partisipasi mereka berkaitan dengan peran para bidan dan kader kesehatan yang ada di Posyandu-Posyandu. Perilaku kesehatan masyarakat terutama perawatan kehamilan ibu dan perawatan anak sudah mulai baik. Sebagian besar para ibu di nagari Pasar Lama Muara Air Haji sudah merawat kehamilan seperti yang dianjurkan kesehatan modern melalui pendidikan yang diberikan bidan desa dan bantuan kader kesehatan.

Sebagian besar ibu-ibu di Nagari Pasar Lama Muara Air Haji tidak ada lagi yang melahirkan ke dukun. Mereka hanya pergi ke dukun urut untuk mengurut kandungannya dengan tujuan untuk memperbaiki letak janin agar mudah melahirkan. Dengan kondisi pelayanan kesehatan yang sudah modern sebagai bagian kehidupan kesehatan masyarakat ini dalam merawat kesehatan mereka. Akan tetapi, pengobatan tradisional masih dianggap diperlukan terutama mengobati penyakit-penyakit tertentu, terutama penyakit yang berbau supranatural, seperti penyakit tasapo. Hal tersebut dipastikan memerlukan peran seorang dukun tradisional.

\section{Saran}

a. Semua pihak terutama keluarga diharapkan berpartisipasi untuk meningkatkan upaya pencegahan terjadinya kematian pada ibu hamil 
dan memperhatikan kondisi anak melalui asupan gizinya, diantaranya dengan pembinaan dan pemberdayaan keluarga yang memiliki resiko gizi kurang pada anak.

b. Pemberdayaan dan pembinaan keluarga ini dapat dilakukan oleh Puskesmas setempat dengan melibatkan perawat kesehatan komunitas.

c. Selain itu perlu dilakukan diseminasi informasi tentang gizi untuk meningkatkan pengetahuan keluarga khususnya ibu tentang asupan nutrisi, cara pengolahan dan pemilihan bahan makanan yang baik pada anak.

\section{Daftar Pustaka}

Ahimsa, 2005. "Kesehatan dalam Perspektif IImu Sosial Budaya" dalam Masalah Kesehatan dalam Kajian IImu Sosial Budaya. Yogyakarta: Kepel Press.

Bungin, Burhan, 2004, Metodologi Penelitian Kualitatif:Aktualisasi Metodologis ke Arah Ragam Varian Kontemporer, Jakarta: PT. RajaGrafindo Persada.

Badan Pusat Statistika, 2012 Survey Demografi Kesehatan Indonesia 2012. Jakarta: Badan Pusat Statistika, Macro International, Bappenas.

Badan Pusat Statistika, 2010. "Sensus Penduduk Indonesia 2010. Jakarta: Badan Pusat Statistika.

Danim, Sudarwan, 2002, Menjadi Peneliti Kualitatif, Bandung: Pustaka Setia.

Emzir, 2011. "Metodologi Penelitian Kualitatif; Analisis Data". Jakarta: PT. Rajagrafindo Persada.

Faisal Sanapiah, 1990. "Penelitian Kualitatif; Dasar-dasar dan Aplikasi". Malang: YA3

Kemenkes RI, 2010. "Laporan Nasional Riset Kesehatan Dasar 2007". Jakarta: Badan Penelitian dan Pengembangan Kesehatan.

Kemenkes RI, 2010. "Indeks Pembangunan Kesehatan Masyarakat". Jakarta: Badan Litbang Kesehatan.

Kemenkes RI, 2012. "Sistem Kesehatan Nasional". Jakarta

Kemkes RI, 2010. "Rencana Strategis Kementerian Kesehatan 2010-1014". Jakarta: Kementerian Kesehatan RI.

Koentjaraningrat, 1979. "Pengantar IImu Antropologi". Jakarta: PT Rineka Cipta.

Mariyah, Emiliana, dkk, 2005. "Hambatan Budaya dalam Interakasi Bidan - Ibu Hamil; Studi Ketaatan untuk Meningkatkan Suplemen dan Status Besi di Puskesmas Banyuurip, Kabupaten Purworejo, Jawa Tengah" dalam Masalah Kesehatan dalam Kajian IImu Sosial Budaya. Yogyakarta: Kepel Press.

Moleong, Lexy, 2001, Metode Penelitian Kualitatif, Bandung: PT.Remaja Rosda Karya.

Neuman, W. Lawrence, 2006, Social Research Methods: Qualitative and Quantitative Approaches $6^{\text {th }}$ Edition, US: Pearson International Edition

Notoatmojo, Soekidjo. 2002. Metodologi Penelitian Kesehatan. Jakarta: Rineka Cipta

Notoatmojo, Soekidjo. 2010. Ilmu Perilaku Kesehatan. Rineka Cipta, Jakarta

Ratna, Nyoman Kutha, 2010. "Metodologi Penelitian; Kajian Budaya dan IImu Sosial Humaniora Pada Umumnya". Yogyakarta: Pustaka Pelajar.

Rudito, Bambang dan Melia Famiola, 2008, Social Mapping (Metode Pemetaan Sosial): Teknik Memahami Suatu Masyarakat atau Komuniti, Bandung: Rekayasa Sains.

\section{Internet}

http://iannnews.com/ensiklopedia.php?page=budaya\&prov=3\&id=315 diakses pada tanggal 16 Februari 2012, pukul 13.10 WIB 